\title{
Sex Difference of Pinnal Hyperemia in Magnesium-Deficient Rats: Effects of Castration and Administration of Sex Hormone
}

\author{
Akira NISHIO, Asayo MIYAZAKI, Shigeru ISHIGURO \\ and Noboru MIYAO \\ Department of Veterinary Pharmacology. Faculty of Agriculture. \\ Kagoshima University, Kagoshima 890, Japan \\ Accepted January 16, 1986
}

\begin{abstract}
In the course of studies on the effects of magnesium ( $\mathrm{Mg}$ ) depletion in the diet $(0.001 \% \mathrm{Mg})$ on mature rats (10 week-old), it became apparent that females developed less hyperemia than males. In the females, the time of onset and severity of hyperemia were enhanced by castration, but not in the males. These data suggest that the development of hyperemia in $\mathrm{Mg}$-deficient adult rats depends on the female sex hormone. The effects of administration of estradiol were examined, using immature rats ( 3 week-old), in relation to hyperemia and histamine metabolism. Two to 3 days after feeding young male and female rats a $\mathrm{Mg}$-deficient diet, the pinnal hyperemia appeared in the same degree. The hyperemia was reduced by the administration of estradiol benzoate $(0.04-0.08 \mathrm{mg} / 100 \mathrm{~g}$ body wt. per day, s.c.) every day. The increments in urinary histamine excretion, splenic histamine content and histidine decarboxylase activity during $\mathrm{Mg}$-deficiency were markedly reduced by the administration of estradiol. The sex difference in the hyperemia which appeared upon $\mathrm{Mg}$-depletion depends on the effects of the female hormone. estradiol, on histamine metabolism.
\end{abstract}

It has been reported that pinnal hyperemia is the first visible symptom of experimental Mg-deficiency in rats (1-6). This hyperemia was reduced completely by the administration of $\mathrm{H}_{1}$ - and $\mathrm{H}_{2}$-antagonists (6). Degranulation of mast cells in several subcutaneous sites $(7,8)$, increased histidine decarboxylase activity and decreased diamine oxidase activity (9) are considered to be related to the elevation in blood and urine histamine levels in Mg-deficient rats. There have been some reports about the difference in the metabolism of histamine in male and female rats (10-12).

In the present study, experiments were performed to test the effect of castration on the degree of the hyperemia using adult rats and to determine the effect of administration of sex hormones in relation to hyperemia and histamine metabolism using young rats. A preliminary report of the results was presented previously (13).

\section{Materials and Methods}

Animals and diets: Wistar rats of both sexes, 3 week-old and 10 week-old, were used. Two series of experiments were carried out: (l) 10 week-old rats: Castration or sham-operation was carried out one week prior to feeding of $\mathrm{Mg}$-deficient diet $(0.001 \%$ $\mathrm{Mg}$ ). (II) 3 week-old rats: The weanlings were used. Before the beginning of the experiment, all of them were fed a control diet $(0.07 \% \mathrm{Mg})$ for 3 days. Estradiol benzoate (0.04 or $0.08 \mathrm{mg} / 100 \mathrm{~g}$ body wt.) or testosterone propionate (2 $\mathrm{mg} / 100 \mathrm{~g}$ body wt.) was injected s.c. once daily for 8 days during the feeding of the $\mathrm{Mg}$-deficient diet. Estradiol benzoate and testosterone propionate were obtained from Teikokuzoki Co., Ltd., as Ovahormon benzoate and Enarmon, respectively. Ovahormon benzoate $(0.2 \mathrm{mg}$ estradiol benzoate $/ \mathrm{ml}$ ) was diluted with physiological saline and injected s.c. into a rat in a volume 
of $0.2 \mathrm{ml} / 100 \mathrm{~g}$ body wt. Enarmon $(10 \mathrm{mg}$ testosterone propionate $/ \mathrm{ml}$ ) was injected s.c. into a rat in a volume of $0.2 \mathrm{ml} / 100 \mathrm{~g}$ body wt. The composition of the diet was the same as that reported previously $(5,9)$. The rats were housed in stainless-steel cages and kept at an ambient temperature of $22-24^{\circ} \mathrm{C}$ with a controlled 12-hour light-dark cycle. The rats were allowed to drink deionized water ad libitum.

Preparation of samples and assay methods: The rats were killed by heart puncture under light ether anesthesia. The rats injected with hormone were killed at $5 \mathrm{hr}$ after the last injection. Blood was collected into a heparinized syringe and centrifuged for separation of plasma. The skin of the back, the spleen and duodenum were each removed, weighed and immediately homogenized in 10 volumes of $0.05 \mathrm{M}$ sodium-potassium phosphate buffer ( $\mathrm{pH}$ 7.0) for enzyme assays or $0.4 \mathrm{~N} \mathrm{HClO}_{4}$ for histamine assay. The homogenate with $0.05 \mathrm{M}$ sodium-potassium phosphate buffer was centrifuged for $30 \mathrm{~min}$ at $10,000 \mathrm{~g}$, and the supernatant fluid was used for the enzyme assay. These procedures were carried out at $4^{\circ} \mathrm{C}$. The histidine decarboxylase (HDC; EC 4.1.1.22) and diamine oxidase (DAO; EC 1.4.3.6) activities were assayed by the methods of Kobayashi (14) and Okuyama and Kobayashi (15). respectively. L-[carboxyl- ${ }^{14} \mathrm{C}$ ] histidine with a specific activity of $51 \mathrm{mCi} / \mathrm{mmol}$ and $[1,4-$ ${ }^{14} \mathrm{C}$ ]putrescine dihydrochloride (122 mCi/ mmol) were used in HDC and DAO assays. The radioactive compounds were obtained from Amersham International, Ltd. The protein contents of the samples were determined by the method of Lowry et al. (16). The enzyme activities were calculated and expressed on a tissue protein basis. Histamine in the homogenate with $0.4 \mathrm{~N} \mathrm{HClO}_{4}$ and in the urine were extracted and determined spectrofluorometrically by the method of Shore et al. $(17,18)$. Plasma magnesium and calcium were determined by atomic absorption spectrophotometry. To score the extent of pinnal hyperemia, the following criteria were used: score 0: no hyperemia, score 1: hyperemic at base of the pinna, score 2: hyperemic at half of the pinna, score 3: hyperemic at three quarters of the pinna, and score 4: hyperemic completely on the pinna.

Statistical evaluations: The mean values of the results are shown in the figures and tables. Differences between the means were tested for statistical significance by Student's $t$-test. The significance was established when the probability level was equal to or less than $5 \%$.

\section{Results}

Adult rats (10 week-old): Figure 1 shows the score of hyperemia and the effect of castration on the development of pinnal hyperemia in adult male and female $\mathrm{Mg}$ deficient rats. Male rats developed the hyperemia earlier and more strongly than female rats. There was no clear difference between sham-operated and castrated male rats in the development of hyperemia during Mg-deficiency until the 16th day. In the ovariectomized female rats, the hyperemia appeared earlier and more strongly than in the sham-operated female rats. After the 16 th day of $\mathrm{Mg}$-deficiency, the score of hyperemia in each group was very variable because the hyperemia was accompanied with intense pruritus.

There was no significant difference among male, female, and castrated male and female rats in plasma magnesium and calcium levels during Mg-deficiency (the table was abbreviated).

Young rats ( 3 week-old): It has been shown that the hyperemia induced in $\mathrm{Mg}$ deficient rats is strongly age dependent, being greatest in the young rats (19). The results of Fig. 1 suggest that the sex hormones can influence the development of hyperemia in Mg-deficient rats. Therefore, the experiments with the administration of sex hormones were done using sexually immature young rats (20).

Figure 2 shows the hyperemia in 3 weekold rats during $\mathrm{Mg}$-deficiency, and the effect of the administration of sex hormone on it. There were no clear differences between male and female rats in the time of onset and severity of hyperemia. The daily administration of testosterone propionate had no clear effects on the onset and severity of hyperemia in both sexes, but the animals 


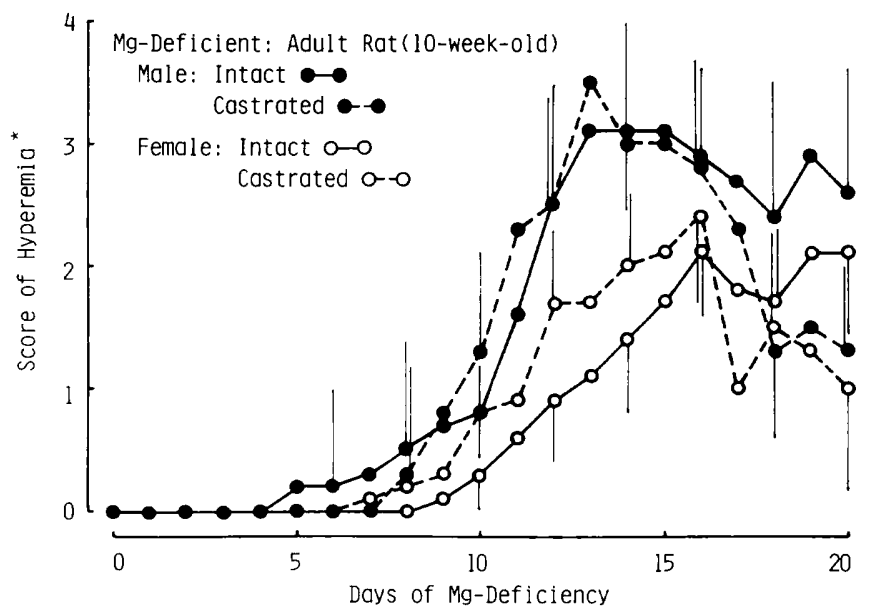

Fig. 1. Pinnal hyperemia in adult Mg-deficient rats, and effect of castration on the score of hyperemia. *The following criteria were used for the scoring of hyperemia: 1: hyperemic at base of pinna, 2: hyperemic at half of pinna, 3 : hyperemic at three quarters of pinna, 4 : hyperemic completely on pinna. Each point represents the mean \pm S.D. of 6 to 10 rats.
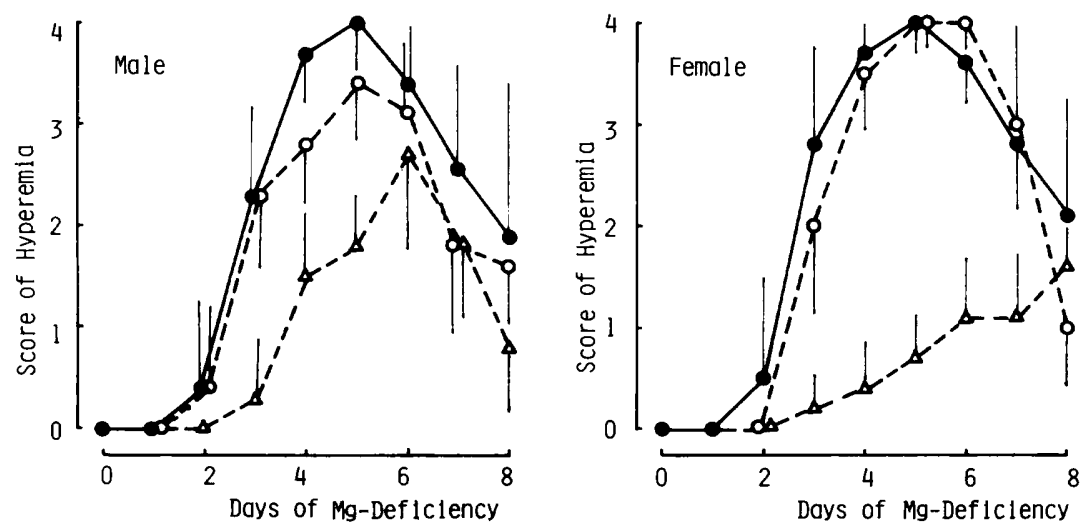

Fig. 2. Effect of sex hormones on the score of hyperemia in young $\mathrm{Mg}$-deficient rats (3 week-old). - Saline $(0.2 \mathrm{ml} / 100 \mathrm{~g}$ body wt. s.c./day for 8 days). $\bigcirc-\bigcirc$ : Testosterone propionate ( $2 \mathrm{mg} /$ $100 \mathrm{~g}$ body wt. s.c./day for 8 days). $\triangle-\triangle$ : Estradiol benzoate $(0.04 \mathrm{mg} / 100 \mathrm{~g}$ body wt. s.c./day for 8 days). Each point represents the mean \pm S.D. of 6 to 20 rats.

treated with estradiol benzoate exhibited weaker hyperemia than non-treated and testosterone-treated rats. The degree of the depression of hyperemia by the administration of estradiol benzoate was more clear in females than in males. There were no significant differences between sex hormonetreated and non-treated rats in plasma magnesium and calcium levels (the figure was abbreviated).

To examine the effect of estradiol on histamine metabolism, the experiments using young female rats were done in relation to hyperemia and urinary histamine excretion (Fig. 3). Time course and severity of hyperemia had a good correlation $(r=0.993)$ to the increase of urinary histamine excretion in saline-treated rats. The administration of estradiol benzoate $(0.04 \mathrm{mg} / 100 \mathrm{~g}$ body wt. per day) delayed the both onset of the hyperemia and increase in urinary histamine excretion. A large dose of estradiol benzoate 

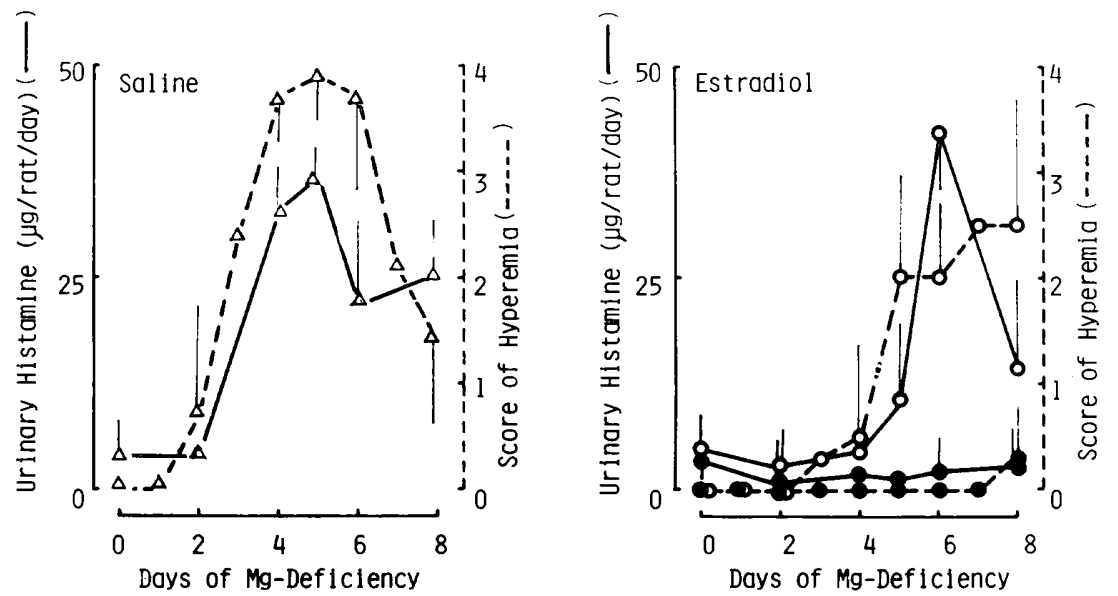

Fig. 3. Effects of estradiol on urinary histamine and score of hyperemia in young female Mg-deficient rats ( 3 week-old). Saline: $0.2 \mathrm{ml} / 100 \mathrm{~g}$ body wt. s.c./day for 8 days. Estradiol benzoate: $0.0 .04 \mathrm{mg} /$ $100 \mathrm{~g}$ body wt. s.c./day for 8 days. Estradiol benzoate: $0.08 \mathrm{mg} / 100 \mathrm{~g}$ body wt. s.c./day for 8 days. Each point represents the mean \pm S.D. of 12 to 20 rats.

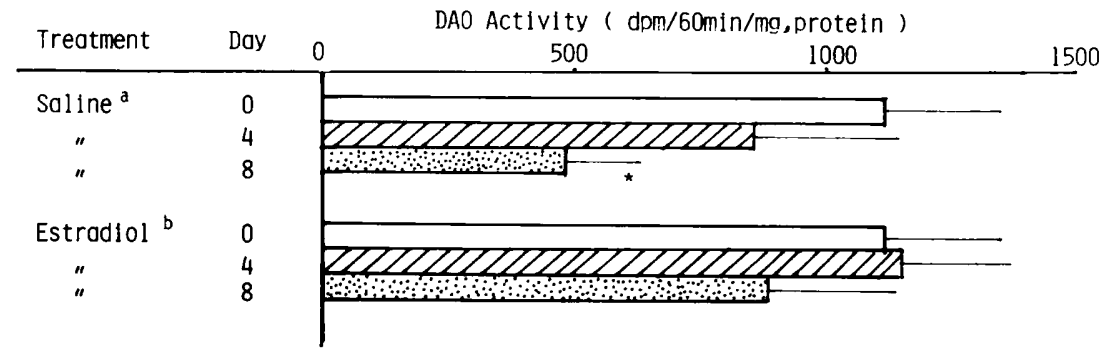

Fig. 4. Effect of estradiol on diamine oxidase activity in duodenum in young female Mg-deficient rats (3 week-old). a: Saline $(0.2 \mathrm{ml} / 100 \mathrm{~g}$ body wt. s.c./day for 8 days). b: Estradiol benzoate (0.08 mg/ $100 \mathrm{~g}$ body wt. s.c./day for 8 days). *Significantly different from 0 day value $(P<0.01)$. Each bar represents the mean \pm S.D. of 4 to 7 rats.

(0.08 mg/100 g body wt. per day) almost inhibited the development of hyperemia and the increase in urinary histamine excretion.

Table 1 shows the effects of the administration of estradiol on histamine contents and HDC activities of the spleen and skin in Mgdeficient female rats. The rats deprived of $\mathrm{Mg}$ in the diet for a period of 4 or 8 days showed increased HDC activity in the both organs. These results were similar to previous reports (5, 9). The histamine content in the spleen increased markedly on the 8th day of $\mathrm{Mg}$ deficiency, but not in the skin. In the spleen, the histamine content and HDC activity increased slightly on the 4th day and increased very markedly on the 8th day: these incre- ments were depressed dose-dependently by the administration of estradiol. In the skin, the increased HDC activity on the 4th day was depressed dose-dependently by the administration of estradiol, but not on the 8th day.

Previously we reported that in the histamine degradatory enzymes, DAO and HMT (histamine methyl transferase; EC 2.1.1.8), DAO activity decreased during Mg-deficiency, but HMT activity did not (9). Figure 4 shows the effect of the administration of estradiol on the DAO activity using young female rats. During Mg-deficiency, the duodenal DAO activity decreased gradually to less than $50 \%$ of that in the control group. The adminis- 


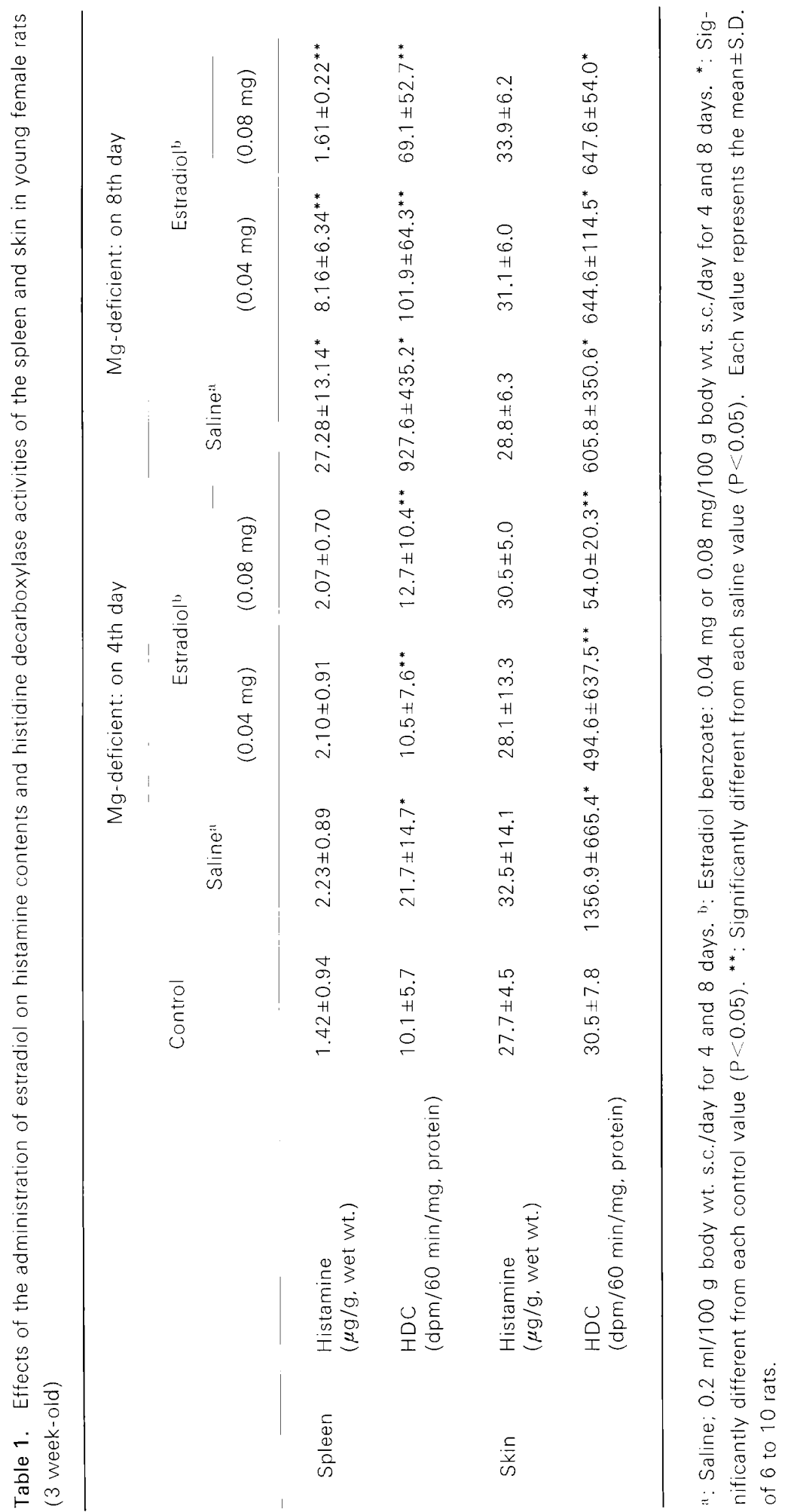


tration of estradiol prevented the decrease of DAO activity.

\section{Discussion}

The present results suggest that the differences in hyperemia in adult rats during Mg-deficiency depend partly on the effects of sex hormone, especially estradiol, on the histamine metabolisms. Previous reports support this hypothesis. Snyder and Axelrod reported that the HMT activity of the kidney in female rats was higher than that in male rats (12). Bélanger showed that the administration of large doses of testosterone to male rats and estradiol to female rats depressed the mast cell population that had been increased in bone marrow (21).

It has been shown that the hyperemia during Mg-deficiency in young rats is caused by the elevated histamine in the blood $(8,21)$. The high histamine in plasma and urine might be the results of mast cell degranulation $(7,8)$, eosinophilia (22-24). basophilia (25) and newly synthesized histamine (9). Recently, we have reported that the elevated HDC activities in the skin and spleen of $\mathrm{Mg}$-deficient rats contribute to the elevation of blood-histamine (9).

The results obtained from the administration of sex hormones to the young rats show the sex difference in the hormoneinduced effect. It has been reported that at 3 weeks of age, the rats show the sex difference in urinary histamine (11). The administration of estradiol to young female $\mathrm{Mg}$-deficient rats inhibited the development of hyperemia dose-dependently. The disappearance of hyperemia was associated with the disappearance of high urinary histamine excretion. This observation suggests strongly that estradiol influences the histamine metabolisms in Mg-deficient rats. The effect of estradiol on young female rats was stronger than that on young male rats. This difference might depend on the presence of estradiol in the peripheral plasma of 3 week-old rats (20, 26).

On the 4th day of $\mathrm{Mg}$-deficiency, the elevated HDC activity of the skin was depressed dose-dependently by the administration of estradiol, but the histamine content was not affected by $\mathrm{Mg}$-depletion and the administration of estradiol. These data suggest that the newly synthesized histamine in the skin could contribute to the high histamine in blood and urine and to the appearance of hyperemia in Mg-deficiency. On the 8th day of $\mathrm{Mg}$-deficiency, HDC activities of the spleen and skin were high, and HDC activity of the spleen was depressed by the administration of estradiol, but HDC activity of the skin was not. It is unclear why the effect of estradiol on HDC activity of the skin is different between the 4th and 8th day of $\mathrm{Mg}$ deficiency. On the 8th day, the hyperemia was depressed completely in spite of the high HDC activity in the skin. This difference between no hyperemia and high HDC activity in the skin could be explained partly by the effect of estradiol on DAO activity. DAO has been reported to participate in decomposition of histamine to an extent of $80 \%$ in rats (27). It has been suggested that the intestinal DAO is one of the important sources of plasma DAO $(28,29)$.

DAO activity was high in the duodenum in control rats, this activity depressed gradually during Mg-deficiency. The administration of estradiol inhibited this depression. The mechanisms are unclear, but it is wellknown that during $\mathrm{Mg}$-depletion in diet the protein synthesis was depressed or modified (30-33) and that the administration of estrogen induced some enzymes $(34,35)$.

Bélanger reported that the bone marrow mast cells increased five to six times during $\mathrm{Mg}$-deficiency, and the administration of estradiol depressed this increase (21). It has been reported that the administration of estradiol induced severe bone marrow depression in ferrets (36). It seems important to determine which cell(s) have the relation to the high histamine and high HDC activity during Mg-deficiency.

It has been reported that the $\mathrm{Mg}$-deficient rats show the decrease in the population of mast cells in their s.c. tissue $(7,8)$. The lack of $\mathrm{Mg}$ might decrease the binding capacity of tissues for histamine, thereby causing a passive release of it (25). The antagonistic effects on the above processes might be considered as one of the possible mechanisms of estradiol.

It is well-known that Mg-deficient rats 
show the decrease in activities of most enzymes, while those of some enzymes are unaffected (37). High HDC activity in Mgdeficient rats might depend on the inhibition of the synthesis of HDC-destroying enzymes, proteases (38). This speculation also seems to be possible in the case of the recovery of DAO activity by estradiol administration.

\section{References}

1 Kruse, H.D., Orent, E.R. and McCollum, E.V.: Studies on magnesium deficiency in animals. I. Symptomatology resulting from magnesium deprivation. J. Biol. Chem. 96, 519-539 (1932)

2 Tufts, E.V. and Greenberg, D.M.: The biochemistry of magnesium deficiency. II. Chemical changes resulting from magnesium deprivation. J. Biol. Chem. 122, 693-714 (1938)

3 Bois, P., Gascon, A. and Beaulnes, A.: Histamine liberating effect of magnesium deficiency in rats. Nature 197, 501-502 (1963)

4 Kraeuter, S.L. and Schwartz, R.: Blood and mast cell histamine levels in magnesium-deficient rats. J. Nutr. 110, 851-857 (1980)

5 Nishio, A., Ishiguro, S., Ikegaki, I. and Miyao, N.: Toxicological and pharmacological studies on the magnesium deficiency in rats. I. Histamine contents in some tissues of magnesium deficient rats. Japan. J. Vet. Sci. 44, 653-659 (1982)

6 Nishio, A., Yoshimitsu, F., Ishiguro, S. and Miyao, N.: Toxicological and pharmacological studies on the magnesium deficiency in rats. 11. Effect of antihistaminics on the hyperemia appearing in magnesium deficient rats. Bull. Fac. Agr. Kagoshima Univ. 33, 141-145 (1983)

7 Bélanger, L.F., Van Erkel, G.A. and Jakerow, A.: Behavior of the dermal mast cells in magnesiumdeficient rats. Science 126, 25-26 (1957)

8 Bois, P.: Effects of magnesium deficiency on mast cells and urinary histamine in rats. Br. J. Exp. Pathol. 44, 151-155 (1963)

9 Nishio, A., Ishiguro, S. and Miyao, N.: Toxicological and pharmacologica! studies on magnesium deficiency in rats: Histamine-metabolizing enzymes in some tissues of magnesiumdeficient rats. Japan. J. Vet. Sci. 45, 699-705 (1983)

10 Westling, $\mathrm{H} .:$ The difference in the metabolism of injected $\left[{ }^{14} \mathrm{C}\right]$ histamine in male and female rats. Br. J. Pharmacol. 13, 498-500 (1958)

11 Westling, $H$. and Wetterqvist, $H .:$ Further observations on the difference in the metabolism of histamine in male and female rats. Br. J. Pharmacol. 19, 64-73 (1962)

12 Snyder, S.H. and Axelrod, J.: Sex differences and hormonal control of histamine methyltransferase activity. Biochim. Biophys. Acta 111, 416-421 (1965)

13 Nishio, A.. Miyazaki, A. and Miyao, N.: Effects of estradiol administration on histamine metabolism in magnesium deficient rats. Japan. J. Pharmacol. 36, Supp. 45P (1984)

14 Kobayashi, Y.: Determination of histidine decarboxylase activity by liquid scintillation counting of ${ }^{14} \mathrm{CO}_{2}$. Anal. Biochem. 5, 284-290 (1963)

15 Okuyama, T. and Kobayashi, Y.: Determination of diamine oxidase activity by liquid scintillation counting. Arch. Biochem. Biophys. 95, 242-250 (1961)

16 Lowry, O.H., Rosebrough, N.J., Farr, A.L. and Randall, R.J.: Protein measurement with Folin phenol reagent. J. Biol. Chem. 193, 265-275 (1951)

17 Shore, P.A., Burkhalter, A. and Cohn, V.H.: A method for the fluorometric assay of histamine in tissues. J. Pharmacol. Exp. Ther. 127, 182186 (1959)

18 Oates, J.A.: Modifications of the Shore method. In Handbuch der Experimentellen Pharmacologie, Edited by Eichler, O. and Farah, A., Vol. XVIII/I, p. 69-72, Springer-Verlag, Berline, Heiderberg and New York (1966)

19 Hunt, B.J.: Age and magnesium deficiency in the rat with emphasis on bone and muscle magnesium. Am. J. Physiol. 221, 1809-1817 (1971)

20 Ramirez, V.D.: Endocrinology of puberty. In Handbook of Physiology, Sect. 7. Endocrinology. Edited by Greep, R.O. and Astwood, E.B., Vol. 2, Part. 1. p. 1-28, Am. Physiol. Soc., Washington, D.C. (1972)

21 Bélanger, L.F.: Variations in the mast cell population of skin and bone marrow in magnesium-deprived rats. The influence of sex hormones. J. Nutr. 107, 2164-2170 (1977)

22 Kashiwa, H.K. and Hungerford, G.F.: Blood leukocyte response in rats fed a magnesium deficient diet. Proc. Soc. Exp. Biol. Med. 99, 441-443 (1958)

23 Claverie-Benureau, P.S., Lebel, B. and GaudinHarding, F.: Changes in histamine and white blood cells in the blood, spleen and thymus of magnesium-deficient rat. Reprod. Nutr. Dev. 21, 591-600 (1981)

24 Kenney, M.A.: Blood cells in the magnesiumdeficient rat related to bone magnesium. Nutr. Rep. Intern. 23, 455-463 (1981)

25 Ishiguro, S., Nishio, A., Miyao, N., Morikawa, Y., Takeno, K. and Yanagiya, I.: Studies on histamine containing cells in the sp!een of magnesium 
deficient rats. Folia Pharmacol. Japon. 83, 15P (1984) (in Japanese)

26 Presl, J., Herzmann, J. and Horský, J.: Oestrogen concentrations in blood of developing rats. J. Endocrinol. 45, 611-612 (1969)

27 Snyder, S.H., Axelrod, J. and Bauer, H.: The fate of ${ }^{4} \mathrm{C}$-histamine in animal tissues. J. Pharmacol. Exp. Ther. 144, 373-379 (1964)

28 Kobayashi, Y., Kupelian, J. and Maudsley, D.V.: Release of diamine oxidase by heparin in the rat. Biochem. Pharmacol. 18, 1585-1591 (1969)

29 Luk, G.D., Bayless, T.M. and Baylin, S.B.: Diamine oxidase (histaminase): A circulating marker for rat intestinal mucosal maturation and integrity. J. Clin. Invest. 66, 60-70 (1980)

30 Schwartz, R., Woodcock, N.A., Blakely, J.D., Wang, F.L. and Khairallah, E.A.: Effect of magnesium deficiency in growing rats on synthesis of liver proteins and serum albumin. J. Nutr. 100, 123-128 (1970)

31 Lizarralde, G., Shane, S.R., Looney, T. and Flink, E.B.: Alterations in hepatic pyrimidine and nucleic acid metabolism in magnesium-deficient rats. Proc. Soc. Exp. Biol. Med. 140, 736-738 (1972)
32 Freude, K.A., Zieve, F.J. and Zieve, L.: Splenic protein synthesis in magnesium deficiency: Mechanism of the inhibition. J. Nutr. 108, 1635-1641 (1978)

33 Watanabe, K. and Iso, K.: Magnesium binding and conformational change of DNA in chromatin. Biochemistry 23, 1376-1383 (1984)

34 Pitot, H.C. and Yatvin, M.B.: Interrelationships of mammalian hormones and enzyme levels in vivo. Physiol. Rev. 53, 228-325 (1973)

35 Kaye, A.M.: Enzyme induction by estrogen. J. Steroid Biochem. 19, 33-40 (1983)

36 Bernard, S.L., Leathers, C.W., Brobst, D.F. and Gorham, J.R.: Estrogen-induced bone depression in ferrets. Am. J. Vet. Res. 44, 657-661 (1983)

37 Aikawa, J.K.: Magnesium deficiency in experimental animals. In Magnesium: It's Biological Significance. Edited by Aikawa, J.K., p. 105116, CRC Press, Inc., Boca Raton (1981)

38 Yamada, M., Watanabe, T., Harino, S., Fukui, H. and Wada, $H_{\text {.: }}$ The effects of protease inhibitors on histidine decarboxylase activities and assay of enzyme in various rat tissues. Biochim. Biophys. Acta 615, 458-464 (1980) 